\title{
Pembuatan tablet effervescent berbahan aktif sediaan kering ekstrak daun senduduk dan bakteri asam laktat asal dadih Sijunjung sebagai minuman fungsional
}

\section{Making of effervescent tablet from dried senduduk leaf extracts and lactic acid bacteria from dadih Sijunjung as functional baverage}

Yulia Helmi Diza*1, Alfi Asben ${ }^{2}$, TutyAnggraini

1 Balai Riset dan Standardisasi Industri Padang

J1. Raya LIK No.23 Ulu Gadut, Padang, Indonesia

2 Fakultas Teknologi Pertanian, Universitas Andalas Kampus Limau Manis, Padang, Indonesia

* e-mail: yuliahelmi1@gmail.com

\begin{tabular}{l}
\hline INFO ARTIKEL \\
\hline Sejarah artikel: \\
Diterima: \\
29 Mei 2019 \\
Direvisi: \\
18 Juni 2019 \\
Diterbitkan: \\
28 Juni 2019
\end{tabular}

\section{Kata kunci:}

effervescent;

dadih;

bakteri asam laktat

(BAL);

senduduk;

antioksidan

\begin{abstract}
ABSTRAK
Pembuatan tablet effervescent dengan bahan aktif ekstrak kering daun senduduk dan sediaan kering bakteri asam laktat yang berasal dari dadih Kabupaten Sijunjung telah dilakukan melalui pencetakan langsung. Penelitian ini bertujuan untuk membuat sediaan minuman fungsional yang mengandung senyawa antioksidan dan bakteri baik yang mudah dan cepat disajikan. Bahan aktif yang digunakan adalah sediaan kering BAL asal dadih sebanyak $2 \%, 4 \%$ dan $6 \%$ dari bahan penyusun tablet dan ekstrak kering daun senduduk sebanyak $15 \%$ untuk semua perlakuan. Terhadap produk yang dihasilkan dilakukan pengujian total BAL, aktivitas antioksidan, total fenol, $\mathrm{pH}$ larutan, kadar air, waktu larut, kekerasan, dan uji kesukaan meliputi penampakan tablet, rasa, warna larutan dan aroma. Hasil penelitian menunjukkan bahwa total BAL yang tumbuh pada larutan tablet effervescent yang memenuhi syarat untuk pangan fungsional adalah perlakuan penambahan sediaan kering BAL $4 \%$ dan $6 \%$, yaitu $4,04 \times 10^{6} \mathrm{kol} / \mathrm{g}, 1,72 \times 10^{7} \mathrm{kol} / \mathrm{g}$, aktivitas antioksidan $52,20 \%$ dan $54,50 \%$ dengan total fenol $0,81 \mathrm{mg} \mathrm{GAE} / \mathrm{g}$ dan $0,86 \mathrm{mg} \mathrm{GAE} / \mathrm{g}$. Dari hasil uji kesukaan diketahui bahwa perlakuan yang mempunyai rata-rata nilai kesukaan tertinggi adalah perlakuan dengan bahan aktif ekstrak kering senduduk 15\% dan sediaan kering BAL 4\% dengan $\mathrm{pH} 5,03$, kadar air 9,34\%, waktu larut 1,875 menit dan kekerasan 4,18 kg.
\end{abstract}

Keywords:

effervescent;

dadih;

lactic acid bacteria

$(L A B)$;

senduduk;

antioxidant

\begin{abstract}
Making of effervescent tables with active ingredients of dried extracts of senduduk leaves and dried preparations of lactic acid bacteria from dadih Sijunjung have been done through direct compression. This study aims to make functional beverage preparations that contain antioxidant compounds and bacteria both easily and quickly served. The active ingredients used were dried LAB preparations from dadih as much as $2 \%, 4 \%$ and $6 \%$ of the constituent tablets and dried extracts of senduduk leaves as much as $15 \%$ for all treatments. The products were tested of total LAB, antioxidant activity, total phenol, $\mathrm{pH}$ of the solution, moisture content, dissolution time, hardness, and test of preference included tablet appearance, taste, solution color, and flavour. The results showed that the total LAB that grown in the effervescent tablet solution met the requirements for functional food was the treatment of the addition of $4 \%$ and $6 \%$ $L A B$ dry dosage, namely $4.04 \times 106 \mathrm{col} / \mathrm{g}, 1.72 \times 107 \mathrm{col} / \mathrm{g}$, antioxidant activity $52.20 \%$ and $54.50 \%$ with total phenol $0.81 \mathrm{mg} \mathrm{GAE/g}$ and $0.86 \mathrm{mg}$ GAE/g. From the test results, it was known that the treatment that had the highest average value of preference was treatment with the active ingredient of dry extract of $15 \%$ and dry preparation of LAB 4\% with pH 5.03, moisture content $9.34 \%$, soluble time 1.875 minutes, and hardness $4.18 \mathrm{~kg}$.
\end{abstract}




\section{Pendahuluan}

Seiring terjadinya peningkatan penyakit degeneratif seperti kanker, diabetes mellitus, jantung dan sebagainya, kebutuhan akan makanan mengalami pergeseran dari waktu ke waktu. Berawal dari istilah empat sehat lima sempurna, bergeser menjadi menu makanan seimbang dan selanjutnya sekarang menjadi makanan fungsional. Makanan fungsional adalah makanan yang memiliki tiga fungsi sekaligus, yaitu dapat memenuhi kebutuhan gizi, dapat diterima oleh konsumen secara sensoris dan makanan tersebut memiliki fungsi untuk menjaga kesehatan, mengurangi terjadinya suatu penyakit dan menjaga metabolisme tubuh (Nugraheny, 2008). Diantara komponen fungsional dalam pangan fungsional adalah antioksidan dan probiotik.

Antioksidan adalah senyawa yang mampu menangkap radikal bebas, karena dapat menyumbangkan satu elektronnya, sehingga radikal bebas yang tidak stabil dapat dinetralkan dan tidak menggangu metabolisme tubuh (Rahmi, 2017). Radikal bebas (free radical) adalah suatu senyawa atau molekul yang mengandung satu atau lebih elektron tidak berpasangan pada orbital luarnya. Adanya elektron yang tidak berpasangan menyebabkan senyawa tersebut sangat reaktif mencari pasangan, dengan cara menyerang dan mengikat elektron molekul yang berada di sekitarnya (Rohmatussolihat, 2009).

Tanaman sikaduduak atau senduduk (Melastoma malabathricum L) merupakan tanaman perdu yang tumbuh di daerah terbuka, tanah lapang, pinggiran sungai, tempat pembuangan sampah, hutan primer dan sekunder, di tepi jalan, di padang rumput, daerah pegunungan dan tersebar diseluruh daerah Asia Tenggara (Joffry et al., 2012) dan juga di bawah perkebunan kelapa sawit (Suteky and Dwatmadji, 2011). Semua bagian tanaman; daun, akar dan batangnya secara tradisional banyak digunakan sebagai obat di Indonesia, Malaysia dan India, namun tidak didukung dengan data klinis.

Kandungan antioksidan dari senduduk telah dilaporkan oleh beberapa peneliti sebelumnya. Daun senduduk mengandung senyawa flavonoid. yang terdiri dari $\beta$-sitosterol, $\alpha$-amyrin, $\quad$ sitosterol-3-O- $\beta$-Dglucopyranoside, quercetin, quercitrin, rutin, patriscabratine, auranamide dan kaempferol-3-O-(2',6'di-O-p-trans-coumaroyl)- $\beta$-glucoside (Susanti et al., 2008; Zakaria et al., 2011). Senyawa-senyawa flavonoid berupa quercetin, quercitrin dan kaempferol3-O-(2',6'di-O-p-trans-coumaroyl)- $\beta$-glucoside menunjukkan aktivitas antioksidan yang lebih kuat dibandingkan dengan vitamin E (Susanti et al., 2008) juga berfungsi sebagai pencegah kanker (Mamat, Siti et al., 2013). Ekstrak air dengan ultrasonic-assisted extraction mengandung asam galat $1,79 \mathrm{mg} / \mathrm{g}$, asam ellagic 0,16 $\mathrm{mg} / \mathrm{g}$ dan total fenol 15,10 g GAE/g (Ambarwati, 2011), mengandung konsentrasi flavonoid yang tinggi dan tanin yang dapat membantu penyembuhan luka (Nurdiana and Marziana, 2013). Ekstrak methanol dari senduduk juga menunjukkan aktivitas antioksidan yang tinggi sebanding dengan asam ascorbat dengan sitotoksisitas yang rendah (Alwash et al., 2014), disamping itu juga disarankan sebagai terapi pengobatan yang potensial untuk diabetes (Kumar et al., 2013). Sementara hasil penelitian (Alnajar et al., 2012) menyatakan bahwa ekstrak etanolnya juga mengandung fenol yang tinggi, yaitu $384.33 \pm 0.005 \mathrm{mg} / \mathrm{g}$ dan kandungan flavonoids sebesar $85.8 \pm 0.009 \mathrm{mg} / \mathrm{g}$ serta menunjukkan bahwa ekstrak aman dan tidak berefek racun sampai dosis 5.000 $\mathrm{mg} / \mathrm{kg}$. Hasil ini juga didukung oleh hasil penelitian (Anggraini and Lewandowsky, 2015) yang menyatakan bahwa daun tanaman senduduk yang diekstrak dengan ethanol berpotensi sebagai sumber senyawa antioksidan alami yang baik dengan kandungan polifenol sebesar $0,44 \%$ dan kandungan antioksidan $68 \%$ pada konsentrasi $0,3125 \mathrm{mg} / \mathrm{L}$.

Tingginya kandungan senyawa antioksidan pada senduduk menjadikannya sebagai salah satu tanaman yang sangat potensial untuk dikembangkan sebagai bahan pangan fungsional. Hal ini ditunjang oleh beberapa hasil penelitian yang memungkinkan untuk menggabungkan senyawa antioksidan dengan bakteri probiotik (Nuryati, 2010; Umam et al., 2012; Zubaidah et al., 2012). Bakteri probiotik diantaranya adalah bakteri asam laktat. Bakteri ini sering dijumpai dalam makanan fermentasi, produk olahan ikan, daging, susu dan buahbuahan, salah satunya adalah Lactobacillus. Dari hasil penelitian (Hardiningsih et al., 2006) diketahui bahwa keberadaan bakteri ini tidak bersifat patogen dan aman bagi kesehatan sehingga sering digunakan dalam industri pengawetan makanan, minuman dan berpotensi sebagai produk probiotik. Bakteri Lactobacillus plantarum dan Lactobacillus casei telah banyak digunakan dalam pembuatan minuman probiotik dan tidak menghasilkan toksin dalam metabolitnya (Khotimah and Kusnadi, 2014). Bakteri tersebut berperan sebagai flora normal dalam sistem pencernaan. Fungsinya adalah untuk menjaga keseimbangan asam dan basa sehingga $\mathrm{pH}$ dalam kolon konstan.

Dadih merupakan hasil fermentasi susu kerbau berasal dari Sumatera Barat yang merupakan produk pangan tradisional (Surono et al., 2008). Diproduksi dari susu kerbau yang difermentasikan secara alami dalam wadah bambu pada suhu kamar selama 24-48 jam. Teknologi pembuatannya sangat sederhana. Setelah diperah, kira-kira sebanyak $150 \mathrm{ml}$ susu kerbau yang baru diperah langsung dimasukkan ke dalam sepotong ruas bambu segar dan ditutup dengan daun pisang. Susu segar tidak diberi perlakuan panas, sehingga proses fermentasi terjadi secara spontan (Sunarlim, 2009). Selanjutnya didiamkan atau difermentasi secara alami dalam suhu ruang selama satu sampai dua hari sampai terbentuknya gumpalan. Proses fermentasi mengandalkan mikroba dari bambu yang digunakan, dapat juga berasal dari daun pisang sebagai penutup bambu dan dari susu itu sendiri. Dalam waktu 24 jam susu akan menggumpal menjadi semacam puding atau tahu putih kekuning-kuningan, kental dan beraroma khas (kombinasi aroma susu dan bambu). Setelah proses fermentasi selesai, dadih dapat langsung dimakan.

Berdasarkan beberapa sumber penelitian telah diketahui bahwa yogurt susu kerbau (dadih) banyak mengandung bakteri asam laktat yang sangat potensial sebagai probiotik (Adrianto, 2011; Elida, 2002; Hardiningsih et al., 2006; Rizqiati et al., 2009; 
Sunaryanto and Marwoto, 2013), seperti Staphylococcus raffinolactis ct 4, Lactococcus piscum dl 4, Leuconostoc paramesenteroides bl2, Leuconostoc mesenteroides al2, Lactobacillus brevis ae4, Lactobacillus casei, serta Lactobacillus plantarum. Kandungan nutrisi yang tinggi dalam dadih susu kerbau, menjadikannya medium yang baik untuk pertumbuhan bakteri asam laktat.

Ekstrak daun senduduk yang memiliki potensi antioksidan yang baik dan bakteri asam laktat yang berperan sebagai probiotik akan dimanfaatkan dalam bentuk sediaan pangan fungsional. Salah satu bentuk sediaan pangan yang mudah dan cepat dikonsumsi berbagai kalangan adalah tablet minuman effervescent. Effervescent memberikan rasa yang menyenangkan akibat adanya proses karbonasi dari asam dan basa. Selain itu, bahan pemanis atau gula bisa ditambahkan untuk menutupi rasa yang kurang menyenangkan, dan bila ditambah dengan air, asam dan karbonat akan bereaksi dan membebaskan karbondioksida yang menghasilkan buih (Diza, 2017). Berkenaan dengan hal tersebut, perlu dilakukan penelitian untuk mendapatkan formula tablet effervescent dengan bahan aktif ekstrak kering daun senduduk dan bakteri asam laktat asal dadih yang memenuhi syarat tablet effervescent dan minuman fungsional yang baik

\section{Metode}

Penelitian pembuatan tablet effervescent dengan bahan aktif berupa sediaan kering BAL hasil isolasi dan identifikasi dari dadih Sijunjung hasil penelitian Diza 2017 dan ekstrak senduduk kering dari hasil penelitian (Asben et al., 2014) dilakukan dengan menvariasikan jumlah bakteri yang ditambahkan dalam produk tablet effervescent dengan konsentrasi penambahan $\mathrm{A}=2 \%, \mathrm{~B}$ $=4 \%$ dan $\mathrm{C}=6 \%$, dan penambahan ekstrak kering daun senduduk sebanyak $15 \%$ dari bahan penyusun tablet untuk semua perlakuan. Rancangan percobaan dilakukan dengan Rancangan Acak Lengkap dengan 3 (tiga) ulangan. Jika hasil hitungan statistik (Uji F) menunjukkan berbeda nyata dilanjutkan dengan uji lanjutan DNMRT pada taraf 5\%.

\subsection{Proses pembuatan tablet effervescent}

Pembuatan tablet effervescent dilakukan menggunakan metode kompresi langsung, dengan mencampurkan ekstrak kering antioksidan daun senduduk konsentrasi tertinggi hasil penelitian (Asben et al., 2014) dengan bahan asam sitrat, asam tartarat, pemanis serta basa natrium bikarbonat menurut formula pembuatan tablet effervescent. Selanjutnya ke dalam campuran ditambahkan sediaan BAL kering sesuai perlakuan, diikuti dengan penambahan lubrikan berupa polietilen glikol 6000 dan dilanjutkan proses pentabletan.

Formulasi yang digunakan dalam pembuatan tablet effervescent mengacu pada formulasi ganul effervescent ekstrak daun gambir oleh (Kailaku et al., 2012) yang dimodifikasi sebagaimana ditampilkan dalam Tabel 1.

\subsection{Analisis}

Metode analisis adalah sebagai berikut: jumlah BAL (Fardiaz, 1993), aktivitas antioksidan (metode DPPH; (Huang et al., 2006), kadar polifenol (Andarwulan et al., 1999), sifat fisik tablet effervescent meliputi kadar air (Pribadi, Yoga et al., 2014), waktu larut (Dewi et al., 2014), kekerasan, $\mathrm{pH}$ larutan serta uji organoleptik untuk mengetahui tingkat kesukaan panelis dilakukan terhadap tablet effervescent meliputi warna, rasa, aroma dan penampakan (Setyaningsih et al., 2010).

Tabel 1.

Formula tablet effervescent probiotik ekstrak senduduk

\begin{tabular}{|c|c|c|c|c|}
\hline \multirow{2}{*}{ Komponen } & \multirow{2}{*}{ Jenis Bahan } & \multicolumn{3}{|c|}{ Formulasi (\%) } \\
\hline & & I & II & III \\
\hline Zat aktif & $\begin{array}{l}\text { Ekstrak kering } \\
\text { daun } \\
\text { senduduk }\end{array}$ & 15 & 15 & 15 \\
\hline \multirow[t]{2}{*}{ Asam } & Asam tartrat & 14 & 14 & 14 \\
\hline & Asam sitrat & 12,5 & 12,5 & 12,5 \\
\hline Basa & $\begin{array}{l}\text { Natrium } \\
\text { bikarbonat }\end{array}$ & 25 & 25 & 25 \\
\hline Pemanis & $\begin{array}{l}\text { Gula jagung } \\
\text { (fruktosa) }\end{array}$ & 32 & 32 & 32 \\
\hline Lubrikan & $\begin{array}{l}\text { Polietilen } \\
\text { glikol }\end{array}$ & 1,5 & 1,5 & 1,5 \\
\hline \multicolumn{2}{|c|}{$\begin{array}{l}\text { Sediaan kering BAL dadih yang } \\
\text { ditambahkan*) }\end{array}$} & 2 & 4 & 6 \\
\hline
\end{tabular}

\section{Hasil dan pembahasan}

\subsection{Total bakteri asam laktat (BAL)}

Hasil penelitian menunjukkan bahwa jumlah koloni yang tumbuh pada tablet effervescent berkisar antara $5,62 \times 10^{5} \mathrm{Kol} / \mathrm{g}$ sampai $1,72 \times 10^{7} \mathrm{kol} / \mathrm{g}$ dengan viabilitas yang baik yaitu $>87 \%$

Tabel 2.

Jumlah koloni bakteri pada tablet effervescent

\begin{tabular}{lll}
\hline Perlakuan & \multicolumn{2}{l}{ Jumlah bakteri yg tumbuh $(\mathrm{kol} / \mathrm{g})$} \\
\cline { 2 - 3 } & Koloni/g & Log \\
\hline $\mathrm{A}$ & $5.62 \times 10^{5}$ & 5.75 \\
\hline $\mathrm{B}$ & $4.04 \times 10^{6}$ & 6.61 \\
\hline $\mathrm{C}$ & $1.72 \times 10^{7}$ & 7.24 \\
\hline
\end{tabular}

Kalau dilihat dari syarat untuk pangan fungsional menurut FAO/WHO bahwa jumlah populasi bakteri yang harus ada dalam kultur starter berkisar $10^{6}-10^{7}$ $\mathrm{cfu} / \mathrm{g}$. Sedangkan (Onayanti et al., 2015) menyatakan bahwa suatu medium pembawa probiotik minimal mengandung mikroba probiotik sebanyak $10^{6}-10^{8}$ $\mathrm{cfu} / \mathrm{ml}$ atau $10^{8}-10^{10} \mathrm{cfu} / \mathrm{g}$ (preparat kering). Hal ini berarti tablet effervescent perlakuan $\mathrm{B}$ dan $\mathrm{C}$ memenuhi syarat sebagai minuman fungsional. 


\subsection{Aktivitas antioksidan}

Nilai aktivitas antioksidan yang dinyatakan dalam \% penghambatan tablet effervescent probiotik ekstrak senduduk terhadap radikal bebas DPPH pada formulasi A, B dan C dapat dilihat pada Gambar 1. Kadar antioksidan dalam tablet effervescent berasal dari ekstrak senduduk kering yang ditambahkan dalam jumlah yang sama sebagai bahan aktif dalam tablet. Penggunaan ekstrak senduduk dalam pembuatan tablet effervescent ini memang diharapkan memberikan manfaat sebagai sumber antioksidan. Nilai aktivitas antioksidannya berkisar dari 49,02 $\pm 0,27 \%$ sampai dengan 54,50 \pm $0,07 \%$ pada konsentrasi $10.000 \mathrm{mg} / \mathrm{kg}$.

Dari literatur, diketahui bahwa aktivitas antioksidan pada daun senduduk berasal dari golongan flavonoid. Flavonoid merupakan metabolit sekunder tanaman yang termasuk golongan fenol yang memiliki aktifitas antioksidan. Senyawa ini terdapat pada hampir seluruh bagian tanaman seperti daun, buah, biji, kulit dan bunga (Heim, Kelly et al., 2002). Flavonoid yang terdapat dalam ekstrak daun senduduk terdiri dari $\beta$-sitosterol, $\alpha$ amyrin, sitosterol-3-O- $\beta$-D-glucopyranoside, quercetin, quercitrin, rutin, patriscabratine, auranamide dan kaempferol-3-O-(2',6'-di-O-p-trans-coumaroyl)- $\quad \beta$ glucoside (Susanti et al., 2008; Zakaria et al., 2011). Senyawa-senyawa flavonoid berupa quercetin, quercitrin dan kaempferol3-O-(2',6'-di-O-p-trans-coumaroyl)- $\beta$ glucoside menunjukkan aktivitas antioksidan yang lebih kuat dibandingkan dengan vitamin E (Susanti et al., 2008).

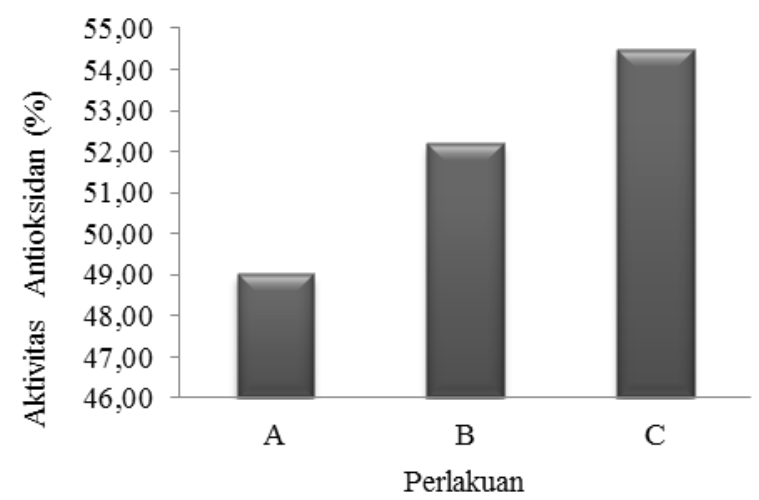

Ket : Perlakuan $\mathrm{A}=$ penambahan sediaan $\mathrm{BAL}$ kering $2 \%$, perlakuan $\mathrm{B}$ $=$ penambahan sediaan $\mathrm{BAL}$ kering $4 \%$, perlakan $\mathrm{C}=$ penambahan sediaan BAL kering $6 \%$.

Gambar 1. Aktivitas antioksidan tablet effervescent probiotik ekstrak daun senduduk.

Selain itu aktivitas antioksidan diduga juga disumbangkan oleh sediaan BAL kering yang ditambahkan sesuai perlakuan. Hal ini disebabkan karena pada saat dilakukan pemanenan suspensi bakteri, terikut juga hasil metabolit bakteri berupa asam laktat. Asam laktat ini mengandung $\alpha$-hydroxyacids (AHA) yang berfungsi sebagai antioksidan dan sering dimanfaatkan untuk pembuatan kosmetik maupun dalam produk pangan (Umam et al., 2012). Dengan demikian semakin tinggi konsentrasi sediaan BAL kering yang ditambahkan akan meningkatkan aktivitas antioksidannya.

Antioksidan adalah senyawa yang dapat menghentikan reaksi propagasi radikal bebas, baik yang berasal dari produk samping metabolisme yang terjadi di dalam tubuh maupun yang berasal dari lingkungan seperti asap rokok, polusi udara, obat-obatan tertentu, sinar ultraviolet, dan radiasi. Radikal bebas (free radical) adalah atom atau molekul yang mempunyai electron tidak berpasangan, terbentuk sebagai hasil antara (intermediet) dalam suatu reaksi organik (Samin et al., 2014). Senyawa antioksidan mampu menangkal atau meredam dampak negatif oksidan dalam tubuh dengan cara mendonorkan elektronnya kepada molekul radikal bebas, sehingga dapat menstabilkan radikal bebas dan menghentikan reaksi berantai. Mengkonsumsi pangan yang mengandung antioksidan dalam jumlah yang memadai dapat menurunkan kejadian penyakit degenerative seperti kanker, kardiovaskular, aterosklerosis, osteoporosis dan lain-lain. Oleh karena itu, antioksidan menjadi komponen yang sangat dibutuhkan tubuh dalam asupan diet sehari-hari.

Tabel 3.

Hasil uji one way anova terhadap aktivitas antioksidan tablet effervescent probiotik ekstrak daun senduduk

\begin{tabular}{ll}
\hline Perlakuan & $\begin{array}{l}\text { Aktivitas } \\
\text { Antioksidan (\%) }\end{array}$ \\
\hline B (Penambahan sediaan BAL kering 2\%) & $49,02 \pm 0,27^{\mathrm{a}}$ \\
C (Penambahan sediaan BAL kering 4\%) & $52,20 \pm 0,13^{\mathrm{b}}$ \\
A (Penambahan sediaan BAL kering 6\%) & $54,50 \pm 0,07^{\mathrm{c}}$ \\
\hline
\end{tabular}

Keterangan : Angka yang diikuti huruf yang sama pada kolom yang sama menunjukkan bahwa variasi perlakuan memberikan hasil tidak berbeda nyata pada tingkat kepercayaan $95 \%$

Dari hasil analisa one way anova diketahui bahwa perlakuan penambahan konsentrasi sediaan BAL kering memberikan pengaruh yang nyata terhadap kadar antioksidan tablet effervescent yang dihasilkan untuk setiap perlakuan seperti ditampilkan pada Tabel 3 .

\subsection{Kadar polifenol}

Pengujian total fenol yang umum digunakan adalah metode menggunakan reagen Folin-Ciocalteu (FC). Reagen FC dibuat dengan campuran sodium tungstat $\left(\mathrm{Na}_{2} \mathrm{WO}_{4} \cdot 2 \mathrm{H}_{2} \mathrm{O}\right)$, sodium molibdat $\left(\mathrm{Na}_{2} \mathrm{MoO}_{4} \cdot 2 \mathrm{H}_{2} \mathrm{O}\right)$, $\mathrm{HCl}, 85 \%$ asam fosforik dan $\mathrm{Li}_{2} \mathrm{SO}_{4} \cdot 4 \mathrm{H}_{2} \mathrm{O}$ yang menghasilkan larutan berwarna kuning yang jernih. Metode ini berdasarkan pada kekuatan mereduksi dari gugus hidroksi fenolik. Semua senyawa fenolik dapat bereaksi dengan pereaksi Folin-Ciocalteu (Samin et al., 2014) membentuk senyawa komplek berwarna biru yang dapat diukur absorbansinya pada panjang gelombang 765 nm (Putri, Dwi et al., 2014).

Kandungan fenolik total dinyatakan sebagai ekuivalen asam galat atau Gallic Acid Equivalent (GAE). GAE merupakan acuan umum untuk mengukur sejumlah senyawa fenolik yang terdapat dalam suatu bahan (Mankosilp, 2004 dalam (Samin et al., 2014). Asam galat digunakan karena tidak mahal, larut dalam air, 
mudah terekristalisasi, kering dan stabil dalam bentuk kering (Singleton and Rossi, 1965).

Dari hasil penelitian diperoleh kadar total fenol tablet effervescent probiotik ekstrak senduduk berkisar antara $0,78 \pm 0,07 \mathrm{mg}$ GAE/g sampai dengan $0,86 \pm 0,02 \mathrm{mg}$ GAE/g (Gambar 2), meningkat dengan semakin bertambahnya konsentrasi penambahan sediaan BAL kering. Namun, dari hasil uji statistik didapatkan bahwa tidak terdapat perbedaan yang nyata kandungan fenolik total pada masing-masing perlakuan seperti ditampilkan pada Tabel 4.

Tabel 4.

Hasil uji one way anova terhadap total poli fenol tablet effervescent probiotik ekstrak daun senduduk

\begin{tabular}{lc}
\hline Perlakuan & $\begin{array}{l}\text { Total Poli Fenol } \\
(\mathrm{mg} \mathrm{GAE} / \mathrm{g})\end{array}$ \\
\hline A (Penambahan sediaan BALkering 2\%) & $0,78 \pm 0,07^{\mathrm{a}}$ \\
B (Penambahan sediaan BALkering 4\%) & $0,81 \pm 0,05^{\mathrm{a}}$ \\
C (Penambahan sediaan BALkering 6\%) & $0,86 \pm 0,02^{\mathrm{a}}$ \\
\hline
\end{tabular}

Keterangan : Angka yang diikuti huruf yang sama pada kolom yang sama menunjukkan bahwa variasi perlakuan memberikan hasil tidak berbeda nyata pada tingkat kepercayaan $95 \%$.

Berdasarkan beberapa penelitian menunjukkan bahwa kandungan total fenol dan aktivitas antioksidan mempunyai korelasi yang sangat kuat, diantaranya 1) (Hadriyono, 2011) melaporkan kandungan fenolik total pada buah manggis memiliki korelasi yang sangat kuat terhadap aktivitas antioksidan dengan nilai 84\%, 2) (Angkasa, 2011) melaporkan korelasi antara kandungan polifenol dan aktivitas antioksidan pada tumbuhan daun hantap adalah sebesar 99\%, 3) (Huliselan et al., 2015) melaporkan bahwa ekstrak etil asetat dari daun sesewanua memiliki kandungan total fenol tertinggi juga memiliki aktifitas antioksidan tertinggi dibanding perlakuan lainnya 4) (Ukieyanna, 2012) menyatakan kandungan fenolik total memberikan kontribusi sebesar $77 \%$ terhadap aktivitas antioksidan pada tumbuhan suruhan, dan 5(Samin et al., 2014) melaporkan bahwa kandungan fenolik total memberikan kontribusi sebesar 93\% terhadap aktivitas antioksidan pada rambut jagung.

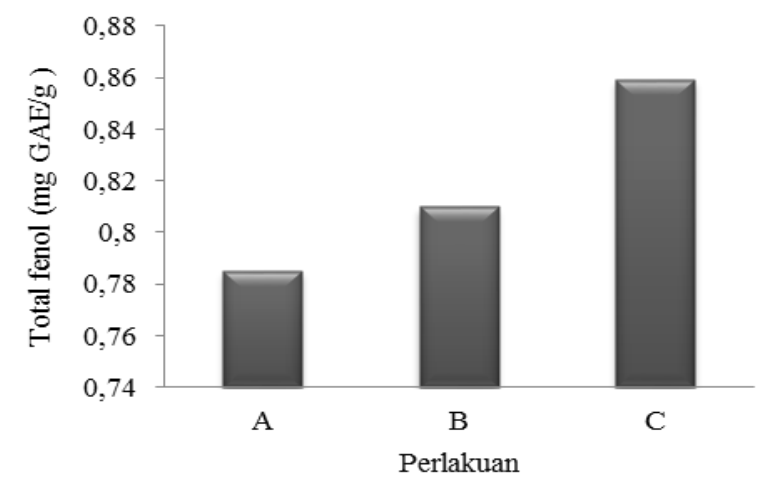

Ket : Perlakuan $\mathrm{A}=$ penambahan sediaan $\mathrm{BAL}$ kering $2 \%$, perlakuan $\mathrm{B}$ $=$ penambahan sediaan $\mathrm{BAL}$ kering $4 \%$, perlakan $\mathrm{C}=$ penambahan sediaan BAL kering $6 \%$.

Gambar 2. Kadar total fenol tablet effervescent probiotik ekstrak senduduk
Hal serupa juga dilaporkan oleh (Pourmorad et al., 2006) bahwa ekstrak dengan kandungan senyawa fenolik yang tertinggi menunjukkan aktivitas antioksidan yang tertinggi pula. Dari hasil penelitian juga didapatkan hasil bahwa meningkatnya konsentrasi penambahan sediaan BAL kering menyebabkan meningkatnya kandungan total fenol yang diikuti oleh meningkatnya aktivitas antioksidan tablet effervescent pobiotik ekstrak daun senduduk.

\subsection{Kadar air tablet (\%)}

Persentase kelembaban tablet effervescent yang dihasilkan masih memenuhi kadar air sediaan tablet effervescent pada suplemen kesehatan yaitu sebesar $\leq 10 \%$ (BPOM, 2015), yaitu perlakuan $\mathrm{A}=8,60 \pm$ $0,13 \%$, perlakuan $\mathrm{B}=9,34 \pm 0,36 \%$, dan perlakuan $\mathrm{C}=$ $10,41 \pm 0,37 \%$ (Gambar 3). Kadar air ini dipengaruhi oleh bahan aktif penyusun tablet yaitu ekstrak senduduk kering dengan kadar air 7,59\% dan sediaan BAL kering dengan kadar air 8,53\% dengan matrik enkapsulan yang bersifat higoskopis, sehingga tablet effervescent sebaiknya disimpan dalam wadah yang kedap udara agar dapat disimpan dalam waktu yang lama.

Tabel 5.

Hasil uji one way anova kadar air tablet effervescent probiotik ekstrak daun senduduk

\begin{tabular}{ll}
\hline Perlakuan & Kadar Air (\%) \\
\hline A (Penambahan sediaan BAL kering 2\%) & $8,60 \pm 0,13^{\mathrm{a}}$ \\
B (Penambahan sediaan BAL kering 4\%) & $9,34 \pm 0,36^{\mathrm{b}}$ \\
C (Penambahan sediaan BAL kering 6\%) & $10,41 \pm 0,37^{\mathrm{c}}$ \\
\hline $\begin{array}{l}\text { Keterangan : Angka yang diikuti huruf yang sama pada kolom yang } \\
\text { sama menunjukkan bahwa variasi perlakuan memberikan hasil tidak } \\
\text { berbeda nyata pada tingkat kepercayaan 95\% }\end{array}$
\end{tabular}

Berdasarkan perhitungan one way anova yang dapat dilihat pada Tabel 5, diketahui bahwa penambahan konsentrasi sediaan BAL kering memberikan pengaruh yang nyata terhadap kadar air tablet effervescent. Perlakuan penambahan sediaan BAL kering sebanyak $2 \%$ memberi pengaruh yang berbeda nyata dengan penambahan $4 \%$ dan $6 \%$. Semakin tinggi konsentrasi sediaan BAL yang ditambahkan menyebabkan semakin tinggi kadar air tablet.

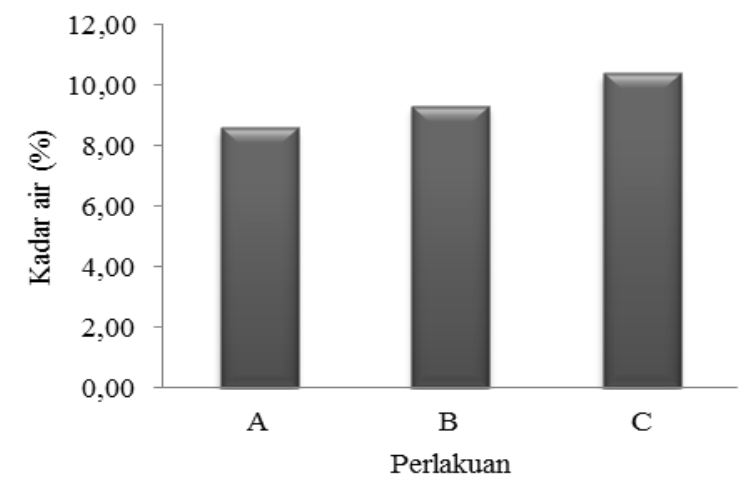

Ket : Perlakuan $\mathrm{A}=$ penambahan sediaan $\mathrm{BAL}$ kering $2 \%$, perlakuan $\mathrm{B}$ $=$ penambahan sediaan $\mathrm{BAL}$ kering $4 \%$, perlakan $\mathrm{C}=$ penambahan sediaan BAL kering $6 \%$.

Gambar 3. Kadar air tablet effervescent probiotik dan ekstrak senduduk pada berbagai perlakuan 


\subsection{Waktu larut tablet effervescent}

Waktu larut menunjukkan banyaknya waktu yang dibutuhkan oleh tablet dalam suatu ukuran saji untuk dapat larut sempurna dalam air dengan volume tertentu. Waktu larut tablet effervescent hasil penelitian yang dilakukan pada suhu ruang adalah perlakuan $\mathrm{A}=1$ menit 39 detik (1,64 $\pm 0,13$ menit), perlakuan $\mathrm{B}=1$ menit 53 detik $(1,88 \pm 0,04$ menit) dan perlakuan $\mathrm{C}=2$ menit 9 detik $(2,16 \pm 0,03$ menit $)$ seperti terlihat pada Gambar 4 . Waktu larut ketiga perlakuan memenuhi syarat waktu larut tablet effervescent, yaitu < 5 menit (BPOM, 2015). Menurut Lachman (2008) dalam (Kholidah et al., 2014) menyatakan bahwa waktu larut tablet effervescent yang baik adalah $1-2$ menit dengan residu dari bahan yang terlarut seminimal mungkin. Sementara itu, menurut Banker dan Anderson (1994) dalam (Pribadi, Yoga et al., 2014) tablet effervescent yang baik memiliki waktu larut tidak lebih dari 1 menit.

Dari hasil penelitian, tablet effervescent yang dilarutkan di dalam air, akan berubah menjadi larutan jernih setelah beberapa saat tablet larut sempurna. Hal ini diduga karena kelarutan dari masing-masing bahan pengisi berpengaruh terhadap kejernihan larutan. Natrium alginat dan skim sebagai bahan enkapsulan bakteri yang digunakan memiliki kelarutan yang cukup baik di dalam air. Dari penelitian lain diketahui bahwa skim bubuk memiliki komponen utama laktosa (sekitar $52 \%$ ) larut lebih baik dalam air dibandingkan dengan whey protein concentrate maupun sodium caseinate, oleh karena itu komponen skim lebih banyak yang larut dan menyebabkan sel release lebih cepat dibandingkan whey protein concentrate maupun sodium caseinate (Adrianto, 2011).

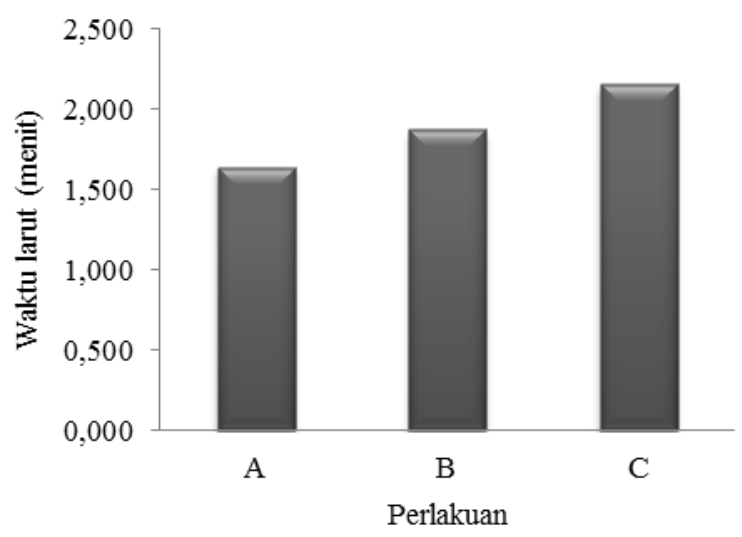

Ket : Perlakuan $\mathrm{A}=$ penambahan sediaan $\mathrm{BAL}$ kering $2 \%$, perlakuan $\mathrm{B}$ $=$ penambahan sediaan $\mathrm{BAL}$ kering $4 \%$, perlakan $\mathrm{C}=$ penambahan sediaan BAL kering $6 \%$.

Gambar 4. Waktu larut tablet effervescent probiotik dan ekstrak daun senduduk pada berbagai perlakuan

Lubrikan untuk produk effervescent haruslah non toxic, tidak berasa, dan larut air. Sangat sedikit lubrikan tradisional yang dapat memenuhi persyaratan ini. Lubrikan yang digunakan dalam pembuatan tablet effervescent probiotik ekstrak daun senduduk ini adalah PEG 6000 yang memiliki sifat dapat larut dengan baik dalam air dan kompatibel dengan bahan yang sensitive dengan kelembaban (Lieberman, 1989 dalam (Dewi et al., 2014).

Tabel 6.

Hasil uji one way anova waktu larut tablet effervescent probiotik ekstrak daun senduduk

\begin{tabular}{ll}
\hline Perlakuan & $\begin{array}{l}\text { Waktu Larut } \\
\text { (menit) }\end{array}$ \\
\hline A (Penambahan sediaan BAL kering 2\%) & $1,64 \pm 0,13^{\mathrm{a}}$ \\
B (Penambahan sediaan BAL kering 4\%) & $1,88 \pm 0,04^{\mathrm{a}}$ \\
C (Penambahan sediaan BAL kering 6\%) & $2,16 \pm 0,03^{\mathrm{b}}$ \\
\hline
\end{tabular}

Keterangan : Angka yang diikuti huruf yang sama pada kolom yang sama menunjukkan bahwa variasi perlakuan memberikan hasil tidak berbeda nyata pada tingkat kepercayaan $95 \%$

Pada Tabel 6 dapat dilihat bahwa perlakuan penambahan konsentrasi sediaan BAL kering memberikan pengaruh yang nyata dalam waktu larut tablet effervescent. Dimana perlakuan penambahan konsentrasi sediaan BAL $2 \%$ tidak berbeda nyata dengan penambahan sediaan kering BAL $4 \%$ dan berbeda nyata dengan penambahan $6 \%$. Semakin banyak penambahan konsentrasi sediaan BAL kering, waktu larut tablet semakin lama. Hal ini diduga disebabkan karena semakin banyaknya bahan pengkapsul (natrium alginat dan skim) yang terikut dalam tablet effervescent, sehingga membutuhkan waktu yang lebih lama untuk dapat larut dengan sempurna.

\subsection{Kekerasan tablet}

Kekerasan merupakan parameter yang menggambarkan ketahanan tablet dalam melawan tekanan mekanis, goncangan serta terjadinya keretakan tablet selama pengemasan pengangkutan dan pendistribusian sampai kepada konsumen. Berdasarkan nilai uji kekerasan menunjukkan bahwa tablet effervescent yang dihasilkan memiliki nilai kekerasan $3,54 \mathrm{~kg}$ sampai dengan $4,85 \mathrm{~kg}$ atau setara dengan $276,07 \mathrm{~N} / \mathrm{cm}^{2}$ sampai dengan 378,68 N.cm² (Gambar 5). Dalam bidang industri, kekuatan tekanan minimum yang sesuai untuk tablet adalah sebesar $4 \mathrm{~kg}$ (Diza, 2017) sedangkan menurut Parrot, 1971 dalam (Wikantyasning et al., 2009) tablet yang baik memiliki nilai kekerasan 4 - $8 \mathrm{~kg}$. kekerasan tablet effervescent yang dihasilkan dalam penelitian ini berada pada kisaran bawah dari nilai kekerasan yang dipersyaratkan untuk tablet. Hal ini diduga disebabkan karena dalam pembuatan tablet tidak menggunakan zat pengikat seperti polivinil pirolidon (PVP) atau zat pengikat lainnya. Bahan pengikat adalah bahan yang digunakan untuk mengikat bahan-bahan lainnya agar ganul yang dihasilkan bertekstur kompak, sehingga produk tidak pecah ketika dikempa.

Perlakuan konsentrasi penambahan sediaan BAL kering ke dalam tablet effervescent memberikan pengaruh yang nyata terhadap kekerasan tablet effervescent yang dihasilkan. Semakin besar konsentrasi penambahan sediaan BAL kering menyebabkan kekerasan tablet semakin berkurang. Hal ini diduga bahan aktif dalam pembuatan tablet effervescent probiotik ekstrak senduduk yang terdiri dari ekstrak kering daun senduduk dan sediaan kering BAL tidak mempunyai ukuran, bentuk, densitas dan kelembaban 
partikel yang sama, sehingga mempengaruhi kekompakan tablet saat dicetak. Semakin tinggi konsentrasi penambahan sediaan BAL kering menyebabkan kekompakan tablet semakin berkurang.

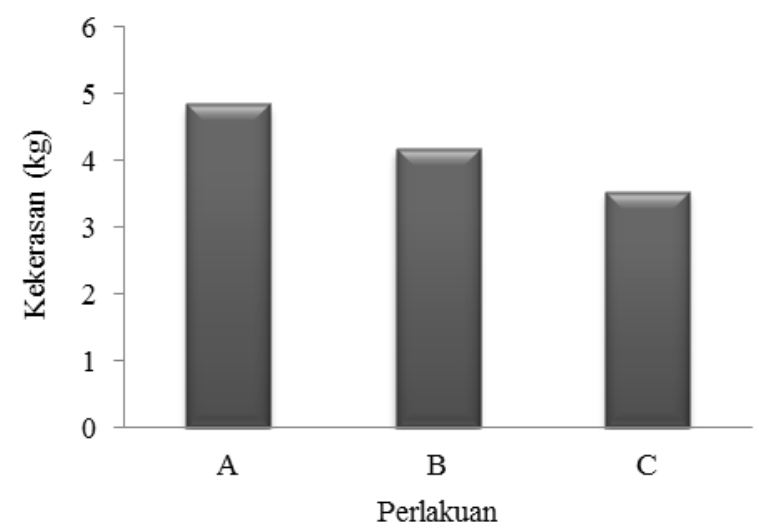

Ket : Perlakuan $\mathrm{A}=$ penambahan sediaan $\mathrm{BAL}$ kering $2 \%$, perlakuan $\mathrm{B}$ $=$ penambahan sediaan $\mathrm{BAL}$ kering $4 \%$, perlakan $\mathrm{C}=$ penambahan sediaan BAL kering $6 \%$.

Gambar 5. Kekerasan tablet effervescent probiotik dan ekstrak daun senduduk pada beberapa perlakuan

Pada Tabel 7 dapat dilihat hasil analisis menggunakan one way anova, yang menunjukkan bahwa perlakuan penambahan konsentrasi sediaan BAL kering sebanyak $2 \%$ memberikan pengaruh yang tidak berbeda nyata dengan perlakuan penambahan $4 \%$, tetapi berbeda nyata dengan perlakuan penambahan $6 \%$.

Tabel 7.

Hasil uji one way anova terhadap kekerasan tablet effervescent probiotik ekstrak daun senduduk

\begin{tabular}{ll}
\hline Perlakuan & Kekerasan $(\mathrm{kg})$ \\
\hline C (Penambahan sediaan BAL kering 6\%) & $3,54 \pm 0,20^{\mathrm{a}}$ \\
B (Penambahan sediaan BAL kering 4\%) & $4,18 \pm 0,37^{\mathrm{ab}}$ \\
A (Penambahan sediaan BAL kering 2\%) & $4,85 \pm 0,20^{\mathrm{b}}$ \\
\hline
\end{tabular}

Keterangan : Angka yang diikuti huruf yang sama pada kolom yang sama menunjukkan bahwa variasi perlakuan memberikan hasil tidak berbeda nyata pada tingkat kepercayaan $95 \%$

\section{7. pH larutan tablet}

Pengujian $\mathrm{pH}$ larutan tablet effervescent dilakukan dengan melarutkan satu tablet effervescent ke dalam 200 $\mathrm{ml}$ aquadest kemudian ukur $\mathrm{pH}$ dengan alat $\mathrm{pH}$ meter. Hasil pengukuran dikatakan baik bila $\mathrm{pH}$ larutan effervescent mendekati netral (Kailaku et al., 2012). Hasil pengukuran $\mathrm{pH}$ larutan tablet effervescent yang dihasilkan adalah 4,89 $\pm 0,01,5,03 \pm 0,02$ dan 5,10 \pm 0,02 seperti terlihat pada Gambar 15. $\mathrm{pH}$ larutan tablet semakin meningkat dengan semakin tingginya konsentrasi penambahan sediaan kering BAL. Hal ini diduga karena dengan semakin banyaknya penambahan sediaan kering bakteri menyebabkan semakin banyak pula matrik enkapsulan yaitu natrium alginat - skim yang ikut terbawa sehingga menaikkan $\mathrm{pH}$. Kisaran $\mathrm{pH}$ ini termasuk pada keasaman rendah, sehingga aman dikonsumsi. $\mathrm{pH}$ yang sedikit asam ini dapat memberikan rasa yang lebih segar pada sediaan effervescent (Lieberman, 1989 dalam (Dewi et al., 2014).

Tabel 8.

Hasil uji one way anova terhadap $\mathrm{pH}$ larutan tablet effervescent probiotik ekstrak daun senduduk

\begin{tabular}{ll}
\hline Perlakuan & pH larutan \\
\hline A (Penambahan sediaan BAL kering 2\%) & $4,89 \pm 0,01^{\mathrm{a}}$ \\
B (Penambahan sediaan BAL kering 4\%) & $5,03 \pm 0,02^{\mathrm{ab}}$ \\
C (Penambahan sediaan BAL kering 6\%) & $5,10 \pm 0,02^{\mathrm{b}}$ \\
\hline
\end{tabular}

Keterangan : Angka yang diikuti huruf yang sama pada kolom yang sama menunjukkan bahwa variasi perlakuan memberikan hasil tidak berbeda nyata pada tingkat kepercayaan $95 \%$

Dari hasil analisis menggunakan one way anova (Tabel 8), menunjukkan bahwa penambahan konsentrasi sediaan BAL kering memberikan pengaruh yang nyata terhadap $\mathrm{pH}$ larutan tablet. Perlakuan penambahan konsentrasi sediaan BAL kering sebanyak 2\% memberikan pengaruh yang tidak berbeda nyata dengan perlakuan penambahan $4 \%$, tetapi berbeda nyata dengan perlakuan penambahan $6 \%$.

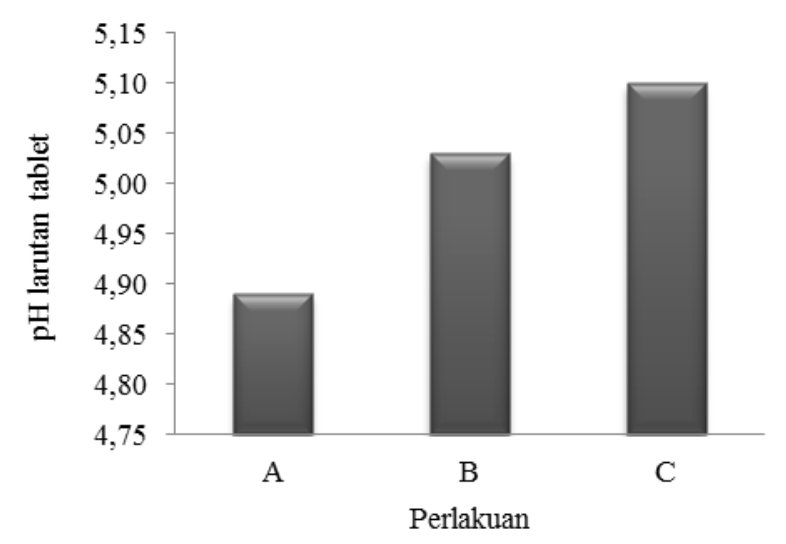

Ket : Perlakuan $\mathrm{A}=$ penambahan sediaan $\mathrm{BAL}$ kering $2 \%$, perlakuan $\mathrm{B}$ $=$ penambahan sediaan $\mathrm{BAL}$ kering $4 \%$, perlakan $\mathrm{C}=$ penambahan sediaan BAL kering $6 \%$.

Gambar 6. pH larutan tablet effervescent probiotik ekstrak daun senduduk pada berbagai perlakuan

\subsection{Uji kesukaan (uji hedonik) tablet effervescent probiotik ekstrak daun senduduk}

Pengujian sensori atau pengujian dengan indera atau dikenal juga dengan pengujian organoleptik sudah ada sejak manusia mulai menggunakan inderanya untuk menilai kualitas dan keamanan suatu produk makanan dan minuman. Salah satu bentuk pengujian organoleptik yang sering dilakukan adalah uji kesukaan atau disebut juga uji hedonik, dimana panelis dimintakan tanggapan pribadinya tentang kesukaan atau sebaliknya (ketidaksukaan). Tingkat-tingkat kesukaan ini disebut skala hedonik. Uji kesukaan terhadap tablet effervescent probiotik ekstrak daun senduduk telah dilakukan oleh 25 (dua puluh lima) orang panelis dengan parameter meliputi penampakan, warna, rasa dan aroma. Dari 25 orang panelis tersebut, yang menyatakan suka dan sangat 
suka terhadap sifat sensoris tablet effervescent probiotik ekstrak daun senduduk dapat dilihat pada Gambar 7.

Panelis akan memberi penilaian khusus terhadap warna larutan, penampakan, aroma dan rasa tablet effervescent probiotik ekstrak senduduk dengan menggunakan skala hedonik. Skala hedonik yang digunakan terdiri dari 5 skala, yaitu: (1) sangat tidak suka; (2) tidak suka; (3) agak suka ; (4) suka dan (5) sangat suka.

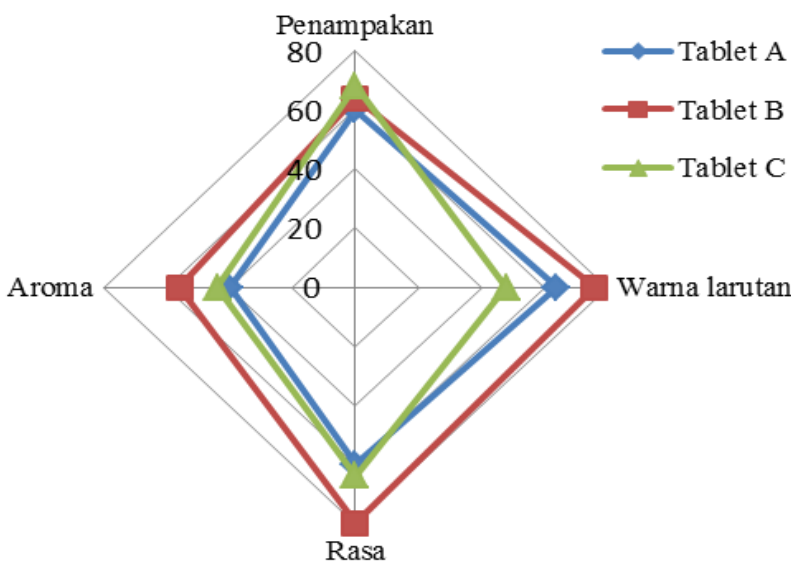

Gambar 7. Gafik hasil uji kesukaan tablet effervescent probiotik ekstrak daun senduduk

Pengujian ini dilakukan untuk mengetahui penilaian masing-masing panelis terhadap produk tablet effervescent probiotik ekstrak senduduk yang disajikan. Dari Tabel 3, diketahui bahwa perlakuan penambahan konsentrasi sediaan kering BAL kering sebanyak 4\% disukai oleh panelis dari segi penampakan, warna, rasa dan aroma lebih dari $50 \%$.

\section{Kesimpulan}

Tablet effervescent yang mengandung BAL dan ekstrak daun senduduk yang memenuhi syarat untuk minuman fungsional adalah pada perlakuan penambahan sediaan BAL kering 4\% dan 6\%. Dari hasil analisa kesukaan, tablet effervescent probiotik ekstrak daun senduduk yang paling disukai dengan nilai warna, rasa dan aroma tertinggi adalah tablet dengan perlakuan penambahan sediaan BAL kering $4 \%$.

\section{Ucapan terima kasih}

Ucapan terima kasih disampaikan kepada Sdr. Dian Pramana Putra yang telah membantu pelaksanaan penelitian ini.

\section{Daftar Pustaka}

Adrianto, 2011. Enkapsulasi Lactobacillus casei dengan teknik ekstrusi sebagai starter untuk pembuatan dadih susu sapi. Institut Pertanian Bogor.

Alnajar, Z.A.A., Abdulla, M.A., Ali, H.M., Alshawsh, M.A., Hadi, A.H.A., 2012. Acute toxicity evaluation, entibacterial, entioxidant and immunomodulatory effects of Melastoma malabathricum. Molecules 17, 3547-3559. https://doi.org/10.3390/molecules 17033547
Alwash, M.S.A., Ibrahim, N., Yaacob, W.A., Din, L.B., 2014. Antibacterial, antioxidant and cytotoxicity properties of traditionally used Melastoma malabathricum Linn leaves. Adv. J. Food Sci. Technol. 6, 6-12.

Ambarwati, D., 2011. Characterization and process optimization of Melastoma malabathricum L extract. UNIVERSITI MALAYSIA PAHANG.

Andarwulan, N., Fardiaz, D., Wattimena, G.A., Shetty, K., 1999. Antioxidant activity associated with lipid and phenolic mobilization during seed germination of Pangium edule Reinw. J. Agric. Food Chem. 47, 3158-3163. https://doi.org/10.1021/jf981287a

Anggraini, T., Lewandowsky, P., 2015. The exotic plants of Indonesia : mahkota mewa (Phaleria macrocarpa), sikaduduak (Melastoma malabathricum Linn) and mengkudu (Morinda citrifolia) as potent antioxidant sources. Int. J. Adv. Sci. Eng. Inf. Technol. 5, 115118. https://doi.org/10.18517/ijaseit.5.2.496

Angkasa, D., 2011. Pengembangan minuman fungsional sumber serat dan antioksidan dari daun hantap (Sterculia oblongata R. Brown.). Istitut Pertanian Bogor.

Asben, A., Anggraini, T., Diza, Y.H., 2014. Pengaruh perbandingan pelarut air dalam maserasi daun senduduk terhadap komponen kimia dan antimikroba ekstrak daun senduduk. Politeknik Pertanian Negeri Payakumbuh, Payakumbuh.

BPOM, R.I., 2015. Persyaratan kadar air pada sediaan tablet dan tablet efervesen peda suplemen kesehatan (No. HK.04.4.42.11.15.1490). Jakarta.

Dewi, R., Iskandarsyah, Octarina, D., 2014. Tablet effervescent ekstrak belimbing wuluh (Averrhoa bilimbi L.) dengan variasi kadar pemanis aspartam. Pharm. Sci. Res. 1, 116-133.

Diza, Y.H., 2017. Kajian pembuatan tablet effervescent probiotik ekstrak daun senduduk (Melastoma malabathricum L) sebagai minuman fungsional. Universitas Andalas.

Elida, M., 2002. Profil bakteri asam laktat dari dadih yang difermentasi dalam berbagai jenis bambu dan potensinya sebagai probiotik. Institut Pertanian Bogor.

Hadriyono, K.R.., 2011. Karakter kulit manggis, kadar polifenol dan potensi antioksidan kulit manggis (Garcinia mangostana L.) pada berbagai umur buah dan setelah buah dipanen. Institut Pertanian Bogor.

Hardiningsih, R., Napitupulu, R.N.R., Yulinery, T., 2006. Isolasi dan uji resistensi beberapa isolat Lactobacillus pada $\mathrm{pH}$ rendah. B I O D I V E R S I T A S 7, 15-17.

Heim, Kelly, E., Tagliaferro, Anthony, R., Bobilya, Dennis, J., 2002. Flavonoid antioxidants: chemistry, metabolism and structure-activity relationships. J. Nutr. Biochem. 13, 572-584. https://doi.org/ 10.1016/S0955-2863(02)00208-5

Huang, Y.-C., Chang, Y.-H., Shao, Y.-Y., 2006. Effects of genotype and treatment on the antioxidant activity of sweet potato in Taiwan. Food Chem. 98, 529-538. https://doi.org/10.1016/j.foodchem.2005.05.083

Huliselan, Y.M., Runtuwene, M.R.J., Wewengkang, D.S., 2015. Aktivitas antioksidan ekstrak etanol, etil asetat, dan n-heksan dari daun sesewanua 
(Clerodendron squamatum Vahl.). J. Ilm. Farm. UNSRAT 4, 155-163.

Joffry, S.M., Yob, N.J., Rofiee, M.S., Affandi, M.M.R.M.M., Suhaili, Z., Othman, F., Akim, A.M., Desa, M.N.M., Zakaria, Z.A., 2012. Melastoma malabathricum (L.) smith ethnomedicinal uses, chemical constituents, and pharmacological properties : a review. Evidence-Based Complement. Altern. Med. 1-48. https://doi.org/10.1155/ 2012/258434

Kailaku, S.I., Sumangat, J., Hernani, 2012. Formulasi granul effervesen kaya antioksidan dari ekstrak daun gambir. J. Pascapanen 9, 27-34.

Kholidah, S., Yuliet, Khumaidi, A., 2014. Formulasi tablet effervescent jahe (Z Officinale Roscoe) dengan variasi konsentrasi sumber asam dan basa. Online J. Nat. Sci. 3, 216-229.

Khotimah, K., Kusnadi, J., 2014. Aktivitas antibakteri minuman probiotik sari kurma (Phoenix dactilyfera L.) menggunakan Lactobacillus plantarum dan Lactobacillus casei. J. Pangan dan Agroindustri 2, 110-120.

Kumar, V., Ahmed, D., Gupta, Pushpraj, S., Anwar, F., Mujeeb, M., 2013. Anti-diabetic, anti-oxidant and anti-hyperlipidemic activities of Melastoma malabathricum Linn. leaves in streptozotocin induced diabetic rats. BMC Complement. Altern. Med. 13, 1-19.

Mamat, Siti, S., Kamarolzaman, Mohamad, F.., Yahya, F., Mahmood, Nur, D., Shahril, M.., Jakius, Krystal, F., Mohtarrudin, N., Ching, Siew, M., Susanti, D., Taher, M., Zakaria, Zainul, A., 2013. Methanol extract of Melastoma malabathricum leaves exerted antioxidant and liver protective activity in rats. BMC Complement. Altern. Med. 13, 1-12. https://doi. org/10.1186/1472-6882-13-326

Nugraheny, M., 2008. Peranan makanan bagi manusia.

Nurdiana, S., Marziana, N., 2013. Wound healing activities of Melastoma malabathricum leaves extract in sprague dawley rats. Int. J. Pharm. Sci. Rev. Res. $20,20-23$.

Nuryati, S., 2010. Aktivitas antioksidan dan daya terima minuman probiotik kedelai hitam dengan jenis mikroba yang berbeda. Universitas Diponegoro Semarang.

Onayanti, N., Budji, Risco, G., Sartini, 2015. Uji Viabilitas Probiotik Asal Saluran Pencernaan Itik Pedaging (Anas domesticus) yang Dienkapsulasi dengan Metode Cross Link.

Pourmorad, F., Hosseinimehr, S.J., Shahabimajd, N., 2006. Antioxidant activity, phenol and flavonoid contents of some selected Iranian medicinal plants. African J. Biotechnol. 5, 1142-1145.

Pribadi, Yoga, S., Sukatiningsih, Sari, P., 2014. Formulasi tablet effervescent berbahan baku kulit buah naga merah (Hylocereus polyrhizus) dan buah salam (Syzygium polyanthum [Wight.] Walp). Berk. Ilm. Pertan. 1, 86-89.

Putri, Dwi, D., Nurmagustina, D.E., Chandra, Agung, A., 2014. Kandungan total fenol dan aktivitas antibakteri kelopak buah rosela merah dan ungu sebagai kandidat feed additive alami pada broiler. J. Penelit. Pertan. Terap. 14, 174-180.
Rahmi, H., 2017. Aktivitas Antioksidan Berbagai Buahbuahan. J. Agrotek Indones. 2, 34-38.

Rizqiati, H., Jenie, B.S.L., Nurhidayat, N., Nurwitri, C.C., 2009. Karakteristik mikrokapsul probiotik Lactobacillus plantarum yang dienkapsulasi dengan susu skim dan gum arab. J.Indon.Trop.Anim.Agric. 34, 139-144.

Rohmatussolihat, 2009. Penyelamat sel-sel tubuh manusia. BioTrends 4, 5-9.

Samin, A.A., Bialangi, N., Salimi, Y.K., 2014. Penentuan kandungan fenolik total dan aktivitas antioksidan dari rambut jagung (Zea mays L.) yang tumbuh di daerah Gorontalo.

Setyaningsih, D., Apriyantono, A., Sari, M.P., 2010. Analisis sensori untuk industri pangan dan agro. IPB Press, Bogor.

Singleton, V.L., Rossi, J.A., 1965. Colorimetry of total phenolics with phosphomolybdic-phosphotungstic acid tegaents. Am. J. Enol. Vitic. 144-158.

Sunarlim, R., 2009. Potensi Lactobacillus SP asal dari dadih sebagai starter pada pembuatan susu fermentasi khas Indonesia. Bul. Teknol. Pascapanen Pertan. 5, 69-76.

Sunaryanto, R., Marwoto, B., 2013. Isolasi, identifikasi dan karakterisasi bakteri asam laktat dari dadih susu kerbau. J. Sains dan Teknol. Indones. 14, 228-233.

Surono, I.S., Nishigaki, T., Endaryanto, A., Waspodo, P., 2008. Indonesian biodiversities, from microbes to herbal plants as potential functional foods. J. Fac. Agric. 44, 23-27.

Susanti, D., Sirat, H.., Ahmad, F., Ali, R.., 2008. Bioactive constituents from the leaves of Melastoma malabathricum L. J. Ilm. Farm. 5, 1-8.

Suteky, T., Dwatmadji, 2011. Anthelmintic activity of Melastoma malabathricum extract on haemonchus contortus activity in vitro. Asian J. Pharm. Clin. Res. 4, 68-70.

Ukieyanna, E., 2012. Antioksidan flavonoid, kadar fenolik dan flavonoid total tumbuhan suruhan (Peperomia pellucida L. Kunth). Institut Pertanian Bogor.

Umam, M.F., Utami, R., Widowati, E., 2012. Kajian karakteristik minuman sinbiotik pisang kepok (Musa paradisiaca forma typical) dengan menggunakan starter Lactobacillus acidophillus IFO 13951 dan. J. Teknosains Pangan 1, 2-11.

Wikantyasning, E.D.R., Nurwaini, S., Willisa, O.Y., Mohandani, I.P., 2009. Formulasi tablet effervescent ekstrak herba sambiloto (Andrographis panicullata (Burm f.) Ness) dan daun dewandaru (Eugenia uniflora Linn.): uji sifat fisik dan respon rasa. J. Farm. Indones. 10, 1-6.

Zakaria, Z.A., Rofiee, M.S., Mohamed, A.M., Teh, L.K., Salleh, M.Z., 2011. In vitro antiproliferative and antioxidant activities and total phenolic contents of the extracts of Melastoma malabathricum leaves. J. Acupunctur Meridian Stud. 4, 248-256. https://doi.org/10.1016/j.jams.2011.09.016

Zubaidah, E., Saparianti, E., Hindrawan, J., 2012. Studi aktivitas antioksidan pada bekatul dan susu skim terfermentasi probiotik (Lactobacillus plantarum B2 and Lactobacillus acidophillus). J. Teknol. Pertan. 13, 111-118. 